\title{
WHAT HAS JOB SATISFACTION GOT TO DO WITH EMPLOYEE COMMITMENT? A RESEARCH STUDY ON LMX AND WORK ATTITUDES
}

\author{
*Ela ÜNLER ÖZ \\ *Tomru DEREKÖYLÜ \\ *Şirli Ender BÜYÜKBAY \\ *Didem YILDIZ \\ *Bahçeşehir University, Turkey
}

\begin{abstract}
The purpose of the study is determining the effect of both leader-member relations (LMX) and job satisfaction on organizational commitment; taking job satisfaction as mediating factor. According to the analysis it was found that high quality LMX positively affect job satisfaction. Additionally, the three stage of regression analysis between organizational commitment and LMX resulted with LMX affecting loyalty and necessity commitment. As main purpose of the study, the mediating affect of job satisfaction on relation between LMX and organizational commitment was measured, and it was found that job satisfaction mediates (by 60\%) the relationship between loyalty commitment and LMX. Moreover, when gender differences in job satisfaction were measured, it was found that female employees have higher job satisfaction level than their male workmates. Implication of the present study is that leaders should be aware of the important linkages between job satisfaction, organizational commitment, and performance. Supervisors need to be aware of how to maximize high LMX relationships among their subordinates.
\end{abstract}

Keywords: LMX, Satisfaction, Commitment

\section{INTRODUCTION}

Leadership is one of the core topics which frequently discussed and studied in organizational behavior literature. It has begun to be defined in the 1840s, by emphasizing a good leader; "a man, born not made". Later, questions such as; "Who are good leaders?" and "How do good leaders behave?" were investigated with the Ohio State and Michigan State University studies respectively. With the pursue to explain leadership, several theories and approaches were set forth; leaders were attributed with numerous personality traits, defined with several leadership skills, and their behaviors were associated with certain contexts (Northouse, 2013). Nonetheless, as focusing on the leader alone would yield insufficient knowledge on the matter, so researchers focused on the dyadic relationship between the leader and subordinates, whereby proposed the Leader-Member Exchange (LMX) theory.

LMX theory, which was initially proposed as Vertical Dyadic Linkage theory, at first focused on the nature of the relations leaders formed with their followers, where later addressed how leader-member relationship (LMX) was related to organizational effectiveness. Among the widely researched topics are the quality of leader-member relationship and its effects on job attitudes; and it was found that, the quality of LMX in the workplace can often affect the entire structure and success of the organization (Mardanov et al. 2008-b). Another widely researched subject is the relationship between employee and manager, which can be crucial for different job attitudes. Burns \& Otte's study on LMX theory (1999), claim that the quality of a leader-member dyadic relationship predicts more positive organizational outcomes than the traits or behaviors of supervisors (Mardanov et al. 2008-b). Moreover, LMX is found to be positively related to important organizational behaviors (Harris et al. 
2009); in the sense that positive conceptions and evaluations of followers were predicted to associate with a higher quality of LMX with their subordinates, leading to increased organizational citizenship behaviors, increased organizational commitment, increased job satisfaction, and higher performance of followers (Duong 2011).

In the current study we focused on the effect of leader member relation (LMX) on job satisfaction and organizational commitment. Our purpose was to investigate the relationship between LMX and work outcomes, where job satisfaction is analyzed as mediator; and organizational commitment is analyzed as dependent variable. Past research show the positive relation between LMX and job satisfaction, as well as the impact of LMX on organizational commitment. However, in the present research we wished to understand whether LMX has any affect on organizational commitment through the mediation of job satisfaction. In other words, we aimed at determining the level of impact of job satisfaction on the level of commitment of employees who experienced high quality of LMX. In search of this, we administered our survey to employees working in the service and production industries in Istanbul, Turkey.

In the following sections, literature on leader-member exchange (LMX) theory is provided, explaining its relation with various leadership approaches, transactional, transformational, servant and paternalistic leadership, and connecting it with the work attitudes, job satisfaction and organizational commitment; our research model and the hypotheses are introduced; where finally results and future research implications are discussed.

\section{LITERATURE REVIEW AND HYPOTHESES}

\section{Leader Member Exchange (LMX)}

Leader-Member Exchange (LMX) theory is grounded on the basis of the interaction and quality of relationship between leader and subordinate. Its initial form is known as the Vertical Dyad Linkage (VDL) theory, suggesting that there is a dyadic relationship between leaders and their followers, during the leadership process. The theory focuses on the nature of the vertical linkages leaders create with each of their followers and their relationship to the work unit. It has developed against the arguments of the early leadership theories -leaders engage in single style of leadership with all subordinates (Danserau et al., 1975; Graen \& Cashman, 1975; Dunegan, 2003; in Kim et al., 2010); whereas it argues that leaders, consciously or unconsciously, demonstrate different behaviors toward different members of their work groups (Graen et al., 1972; Orris \& Johnson, 1973; in van Breukelen et al., 2006). While they establish a high-quality relationship through building a sense of mutual trust, respect and loyalty with some followers (in-group), their interactions with other followers is limited within the formal contacts (out-group).

In the early 1980s, the VDL 'in-group - out-group approach' has become as the Leader-Member Exchange (LMX) theory. Until then, defining a leader has been based upon the role and behavior of leaders, either from the leaders 'point of view -as in trait approach, skills approach, style approach; or through the subordinates' and context point of view -as in situational leadership theory, contingency leadership theory, and path-goal theory. However, distinct from above theories, LMX emphasizes the quality level of interaction between leader and members and proposes that both contribute to the exchange in developing a high-quality working relationship. In that sense, LMX can be considered as a process approach; since the leader and subordinates are the active participants of the process, while it can as well be characterized as a transactional approach (van Breukelen et al., 2006).

In fact, the differentiated relationships between leader and followers emerge based on how well team members work with the leader and how well the leader works with them. A leader's relationship varies from one subordinate to another, based on the level of involvement of subordinates in expanding their role responsibilities with their leader (Berneth et al., 2007). Thus, a high quality of leader-member relationship is developed with some subordinates, while a low quality of leadermember relationship is created with other (O'Donnel et al., 2012). As what Dansenrau, (1975) and Graen (1976) posited -that most leaders develop such 'high-quality' exchange relationship with few subordinates (van Breukelen et al., 2006), may be characterized as discrimination between subordinates (Dansenrau, 1995; in van Breukelen et al., 2006), forming the 'in-group' versus the 'out- 
group' members (Graen \& Cashman, 1975; in Northouse, 2013); or 'trusted assistants' versus 'hired hands' (Zalensky \& Graen, 1987; in Kim et al., 2010); or employees with 'high-quality versus 'lowquality' LMX (Graen \& Uhl-Bien, 1987; in Kim et al., 2010). The 'in-group' consists of highly valued employees with whom the leader forms a high quality of relationship, intensive communication and coordination that is based on expanded and negotiated role of responsibilities, that are extra working hours and task completion beyond job roles. Members of the 'in-group' are observed to be willing to do more work for the group or the leader, in return receive more information, influence, confidence and concern from their leaders. Employees who perceive higher quality LMX relationship with their leader feel obliged to work harder, hence leading to desired organizational outcomes (Kim et al., 2010). While they do extra effort for the leader, the leader does similar for them; provides better work-related benefits, sources of information. In contrast, those who are less willing to take on new and different job responsibilities, become part of the 'out-group', who usually come to work, do their job and go home. They have superficial and less compatible contact with the leader (van Breukelen et al., 2006), based on formal employment contract and defined roles.

Of course, although its distinctive nature, LMX bears similarities and differences with some leadership types. Hence, for better conceptualization, in the following section, we briefly analyzed leadership styles that may be associated with the Leader-Member Exchange Theory.

\section{LMX vs. Transactional Leadership}

LMX theory may have similarities with transactional leadership. Transactional Leadership model was defined by Bass (1985), as a process of exchange based upon subordination to the leader. According to Burns (1978), transactional leadership was based on an exchange process between leaders and subordinates and rewards were administered to employees in accordance to acceptable levels of displayed effort and performance. The followers comply the requests of their leader, due to their formal obligation and the economic rewards the leader controls. Transactional leadership is based more upon the fundamental ideas of managerialship and behavior modification (Skinner, 1953).

Furthermore, transactional approach may be characterized as LMX, since both the leader and the followers are seen as active participants (Hollander, 1980). Yukl mentioned that the LMX model is a transactional approach, arguing that it "describes how leaders use their position power [organizational resources] to develop different exchange relationships with different subordinates" (Yukl, 1989: 40)

Eagle and Lord (1997) supported that the quality of LMX was higher if there was a match between leaders' and subordinates' styles of implicit leadership. At the lowest level of LMX quality, leaders are transactional (Kuhnert \& Lewis, 1987), where leadership is associated with lower quality exchange (Graen and Uhl-Bien 1995). According to leader's level of engagement with followers and activity level, Bass (1985) differentiated two types of transactional leadership_contingent reward and management-by-exception. Howell and Hall- Merenda (1999) reported positive correlations of LMX with contingent reward leadership but not with management by exception; because the former attends less to the relational aspects of leadership and more to defining the task and level of performance expected from followers (Howell\& Hall-Merenda; 1999).

LMX is both transactional and transformational because it begins as a transactional social exchange and may evolve into a transformational social exchange (Graen and Uhl-Bien; 1995).

\section{LMX vs. Transformational Leadership}

Transformational leadership is positively related to the amount of effort followers are willing to exert, satisfaction with the leader, ratings of job performance, and perceived effectiveness (Bass, 1998). It has four key dimensions, - known as the "four I's"; (1) idealized influence or charisma, (2) inspirational motivation, (3) intellectual motivation, and (4) individualized consideration (Felfe et al., 2004; Judge and Piccolo, 2004; Purvanova and Bono, 2009; McLaurin and Al Amri, 2008). Transformational leaders communicate a compelling vision of the future (idealized charisma); provide symbols and emotional appeals to increase awareness of mutual goals (inspirational motivation); encourage followers to question traditional ways of doing things (intellectual stimulation); and treat followers differently but equitably on a one-to-one basis (individualized consideration); (Bass \& 
Avolio, 1993). Research show that quality of leader-follower relationships is positively related to transformational leadership.

Gerstner and Day (1997) argued that transformational leadership seems conceptually similar to the process of developing a unique exchange relationship that is central to LMX and high quality exchanges are transformational in nature for both leader and follower (Gerstner and Day, 1994 and Graen and Uhl-Bien, 1995). LMX has been found to be positively related to transformational leadership (Deluga, 1992). It is an observed research that transformational leaders can create exchange and act as mentors to develop the potential strengths of the subordinates. Additionally, older members may prevent other members to enter into the 'in-group' membership. However this perspective may not be the main concept of transformational leadership, as the leader pays individual attention to every follower and values each's contribution, no matter which group they belong to - 'in group' or 'out group'; and lastly, the leader wants to increase the number of dependent and highly involved followers. This leadership type has the goal to encourage followers to transcend their own self-interests and move beyond simple leader-member transactions, for the good of the group or organization (Burns, 1978; Bass, 1985). This way, it may make the 'out-group' members attracted and have them enjoy closer proximity to the leader. All these are likely to result in an enhanced quality of LMX (Shiva \& Suar; 2011). The leader's effectiveness is often measured by the ability to develop human and social capital among followers. Both LMX and transformational leadership have this common goal. In other words, transformational leaders help followers reframe what the future might be, encourage them to explore alternative possibilities, and coach them to fully develop their potentials. Furthermore, LMX and transformational leadership share two important characteristics: motivation of subordinates and enhanced performance (Judge and Piccolo, 2004; Felfe, Tartler, and Liepmann, 2004; Purvanova and Bono, 2009; Yukl, 1998). Based on research observation, transformational leadership produce significantly higher follower performance in close versus distant situations, whereas LMX produce high follower performance irrespective of physical distance between leaders and followers (Howell \& Hall-Merenda, 1999).

Deluga noted that "transformational leaders may foster the formation of high quality relationships and create a sense of a common fate with individual subordinates; while in a social exchange process, subordinates strengthen and encourage the leader" (1992: 245). Studies have linked transformational leadership to high levels of efforts that the members put (Seltzer and Bass 1990), trust in the leader (Bass 1990), and the followers' respect for the leadership (Conger et al. 2000).

Many authors have highlighted the similarities between the constructs of LMX and transformational leadership (Gerstner \& Day, 1997). However, some researchers have argued that LMX is distinct from transformational leadership; in the fusion of goals of leader and follower. Burns (1978) considered the fusion of goals between leader and follower to be an essential component of transformational leadership. LMX on the other hand, even when it is a high quality exchange relationship or has reached the final stage of mature relationship, does not address the question of changing the goals or value systems of followers (Kristhan, 2005). Another difference is; while transformational leaders persuade individuals to suspend personal interests for the sake of collective and to equate their own success with their contribution to organizational effectiveness (Bass, 1985), LMX is more focused on individual outcomes, such as personal growth and career development (Scandura \& Schriesheim, 1994). It is likely that LMX is more beneficial for employee career related outcomes and well-being, while transformational leaders are more engaged in building collective effectiveness (Bryman, Collinson, Grint, Uhl-Bien and Jackson, 2011).

Also Howell and Hall-Merenda (1999) found LMX to be more strongly related to individual performance than transformational leadership. Piccolo and Colquitt (2006) made a study of 217 individuals from a broad cross-section of job types, and found that compared to transformational leadership, LMX is more proximal to individual attitudes and behaviors across organizations in a wide variety of industries.

While the focus of LMX theory is on relationships and outcomes (Greguras and Ford, 2006), focused on increasing one's own advantages over others, transformational leadership emphasizes the vision, 
ideals, values of the leader (McLaurin and Al Amri, 2008) and mainly focused on communicating a higher vision to employees.

\section{LMX vs. Servant Leadership}

Leaders can play a critical role in helping employees to realize their potential (Liden, Wayne, \& Sparrowe, 2000). Servant leadership, first theorized four decades ago (Greenleaf, 1970), was described as a leadership philosophy that values service to others over self-interests, developing employees to their fullest potential in the areas of task effectiveness, community stewardship, selfmotivation, and future leadership capabilities. Servant leadership differs from traditional approaches to leadership, that it stresses personal integrity and focuses on forming strong long-term relationships with employees. Servant leaders place the needs of their subordinates before their own needs and center their efforts on helping subordinates grow to reach their maximum potential and achieve optimal organizational and career success (Greenleaf, 1977). This leadership approach may be considered as one of the most closely tied leadership type, -after transformational leadership, to leader-member exchange (LMX) theory. It is observed that in servant leadership theory, the social exchange is described by high-quality relationship, which defines the most effective relation between the leader and follower. Despite the overlap between servant leadership and LMX, LMX theory is silent with respect to the provision of personal healing, the development of followers into servant leaders, and the encouragement of service to the community. A study done by Barbuto \& Hayden (2011), servant leadership dimensions were tested for relationship to LMX quality, and they found that the measure of servant leadership style is strongly related to improved quality of leader-member exchanges. Moreover, servant leadership was found to be a strong predictor of leader-member exchange quality. Especially the five sub-scales - altruistic calling, emotional healing, wisdom, persuasive mapping, and organizational stewardship are positively related to Leader-Member Exchange Theory.

\section{LMX vs. Paternalistic Leadership}

Paternalism indicates that managers take a personal interest in the epmloyees' off-the-job lives and attempt to promote their personal welfare while offering career-related support (Gelfand, Erez, \& Aycan, 2007).

According to LMX theory, effective leadership occurs when leaders and followers maintain a highquality relationship characterized by mutual trust, respect, and obligation (Graen \& Uhl-Bien, 1995). The leader's emotional support and shared values make subordinate strong in the organization (Sparrowe \& Liden, 1997). In high LMX relations, leaders count on their followers to provide them with assistance and reciprocally followers rely on their leaders for support and career investment (Graen \& Uhl-Bien, 1995). According to Pellegrini and Scandura (2006), high- quality LMX relationships may also positively influence the protection and care provided in paternalistic leadership.

The studies show that there are some differences between paternalistic leadership and LMX. Pellegrini, Scandura and Jayaraman (2010) stated that LMX is focused on employee's career development, whereas paternalism is focused on the employee's overall welfare both in work and offthe-job domains. In other words, the main idea of paternalism is longer commitment to the relationship. On the other hand, LMX relations involve an economic component (Liden, Sparrowe, \& Wayne, 1997), whereas in paternalistic leadership the relationship is based on personal commitment that is driven by obligation and loyalty that goes beyond work transactions. Pellegrini, Scandura and Jayaraman (2010) states that paternalism is somehow "relationships as interpersonal attachment", that primarily involves social transactions.

In paternalistic leadership, decision-making is directive rather than empowering (Uhl-Bien \& Maslyn, 2005) but LMX employs participative management, such as empowerment and delegation to advance the decision-making skills of the subordinate (Schriesheim, Neider, \& Scandura, 1998). 


\section{LMX and its Relationship with Work Attitudes}

\section{LMX and Job Satisfaction}

Job satisfaction is one of the main measures for job attitude and it was widely researched in the organizational behavior area. Organ \& Konovsky (1989) claimed that job satisfaction may be treated as positive emotional state reflecting an effective response to a job situation. Satisfaction at job does not mean absence of dissatisfaction, but employee's attitude towards work (Duong 2012). Pool (1997) claimed that job satisfaction is an attitude which individuals form and maintain about a job, and this attitude is developed from their perceptions of the job (Mardanov et al. 2008-a).

There are several researches to explain job satisfaction and LMX relationship and it is assumed that job satisfaction has the highest correlation with high quality leader member relationship compared to other work attitudes. Li et al. (2010), for example, found a positive relationship between LMX and job satisfaction. Harris et al (2009) made research based on self-rated outcomes of job satisfaction and his findings show that LMX was positively and significantly related to job satisfaction and negatively related to turnover intentions. Gerstner \& Day's (1997) meta-analytic findings showed that quality of LMX relationship positively relates to employee task and contextual performance, job satisfaction, and employee turnover intentions (Harris et al. 2009). Fisk and Friesen (2012) found that LMX quality have a direct positive impact on employees' levels of job satisfaction. A strong relationship between a supervisor and employee will create a higher level of member satisfaction with supervision (Mardanov et al. 2008-b). There are also several researches that claim LMX is a strong predictor of job satisfaction (Major et. al 1995, Martin 2005, Volmer 2011; in Volmer 2011). Erdogan and Enders (2007) contended that employees with high quality leader-member relations were more satisfied, while those with low quality relations were least satisfied with their jobs when their supervisor had high perceived organizational support (Liao et al. 2009). In Pellegrini \& Scandura's (2006) study, within a Turkish sample, LMX and job satisfaction were significantly associated (Schroeder 2011). The dyadic relationship between supervisor and employees affect employee job outcomes such as job satisfaction (Aycan, 2006; Pellegrini \& Scandura, 2008; in Schroeder 2011).

Members with high-quality of LMX feel privileged and superior, compared to fellow group members who have not been selected as in-group members, and consequently their job satisfaction is increased (Volmer et al. 2011). Prior studies have shown that in a high quality leader-member relation, leaders provide both intangible and tangible resources to members, which leads to higher job satisfaction (Gerstner and Day 1997; Robbins 2003; Aryee and Zhen 2006; Erdogan and Enders 2007; in Liao et. al. 2009). The LMX theory stipulates that the in-group typically receives preferential treatment, with higher discretion and autonomy at work, coupled with more challenging and important responsibilities. Given this condition, subordinates in the in-group experience higher levels of job satisfaction due to the preferential treatment that they receive as compared to their counterparts in the out-group (O’Connor \& Srinivasan 2010). Based on previous research we assume that;

\section{$\boldsymbol{H}_{1}$ : High quality LMX positively affects job satisfaction.}

\section{LMX and Organizational Commitment}

Organizational commitment is an attitude of company loyalty exhibited by employees (Truckenbrodt 2000). There are several definitions for organizational commitment. Simply, organizational commitment can be defined as the strong desire to be continued to be a member of an organization. It plays a positive role in retention of members in the organization (Liao et al. 2009). Mowday et al. (1979) have defined organizational commitment as individuals believing in and accepting organizational goals and values, willing to remain within their organizations, and willing to provide considerable effort on their behalf (Liao et al. 2009). Allen and Meyer (1990) defined organizational commitment as an attitude that individuals tend to believe that "I would be happy to spend the rest of 
my career with this organization" (Tse \& Lam 2008). According to them organizational commitment is a psychological state that binds the individual to the organization (Farris 2012).

Mowday et al. (1982) also identified three characteristics of organizational commitment: (a) a strong belief in and acceptance of the organization's goals and values; (b) willingness to exert considerable effort on behalf of the organization; and (c) a strong desire to maintain membership in the organization (Joo 2010). Thus, organizational commitment may also affect employees identifying themselves with their organizations. Individuals with higher levels of organizational commitment have a sense of belonging and identification with the organization that increases their desire to pursue the organization's goals and activities, and their willingness to remain part of the organization (Meyer \& Allen 1991; Mowday, Porter \& Steers 1982; in Golden \& Veiga 2008).

Early commitment studies, typically considered as general organizational commitment, are onedimensional construct (Kang et al. 2011). Allen and Meyer (1990) proposed a three component model of organizational commitment which comprised affective or emotional attachment, continuance or perceived cost and normative or obligation to the organization. This model links each component of commitment to specific behaviors exhibited by employees (O'Connor \& Srinivasan 2010). Thus, general commitment is composed of affective, continuance, and normative commitment. Affective commitment is about feeling of identity with an organization, that is associated with the individual's want or desire to remain with the organization (Farris 2012). It refers to the employee's attachment to the organization based on emotional attachment, a sense of belonging, and involvement (O'Connor \& Srinivasan 2010). Normative commitment is associated with the individual's feelings of obligation to the organization (Farris 2012). It stems from the employee's thought that leaving the organization can be a betrayal to organization and colleagues. Wiener (1982) defined it as "the totality of internalized normative pressures to act in a way which meets organizations' goals and interests" effectively suggesting that these behaviors are exhibited because "employees believe it to be the right and moral thing to do" (O'Connor \& Srinivasan 2010). Continuance commitment is about what would happen if the employee leaves the organization; questioning whether it will be costly or inconvenient if the employee leaves the organization? Thus, continuance commitment is associated with the individual's perceived cost of leaving the organization or the need to remain with the organization (Farris 2012). Becker (1960) described it as the tendency to engage in consistent lines of activity based on the individual's recognition of the costs associated with discontinuing the activity (O'Connor \& Srinivasan 2010).

There are several researches in literature that aims at explaining the relationship between organizational commitment and the quality of leader-member exchange. Previous studies on leadermember relations suggest that members with higher quality of leader-member relations are more committed to the organization, than to those with lower quality of relations (Liao et al. 2009). L, Hung and Aafaqi (2007) found that LMX has a positive relationship with organizational commitment. Specifically, relative to other dimensions (contribution and loyalty), affective commitment was found to be related to all components of organizational commitment, but the impact was negative for continuance commitment (Liao et al. 2009). Duchon et al. (1986) reported that employees in higher quality dyads have been demonstrated to be more committed to the organization, than the employees in lower quality dyads; which brought them to the conclusion that LMX correlates with organizational commitment (Kang et al. 2011). Furthermore, the dyadic relationship between supervisor and employees affect employee organizational commitment (Aycan 2006; Pellegrini \& Scandura 2008; in Schroeder 2011).

High quality LMX relationships result in mutual trust, liking, and respect which tend to enhance organizational commitment, while low quality relationships, devoid of such affect, do not (Golden \& Veiga 2008). Normative commitment should be about trust and be loyal to the organization. Thus, high quality leadership might affect normative commitment positively. Duchon, Green and Taber (1986) found that quality of exchange was positively related to the extent to which members were committed to the organization in an examination of antecedents and consequences of LMX in Junior Achievement companies. Yukl (2002) points out that employees in higher quality dyads are more likely to be committed to task accomplishment and to carry out administrative duties for the leader 
(Liao et al. 2009). Truckenbrodt (2000) also found a significant relationship between quality of LMX and organizational commitment.

Nystrom (1990) linked LMX and organizational commitment, finding that employees in higher quality relationships reported higher levels of commitment than the employees in lower quality relationships (O'Connor \& Srinivasan 2010). Individual that enjoy high LMX will have high affective organizational commitment (Ariani 2012). Gregson (1992) conducted a research showing that job satisfaction is a causally antecedent of organizational commitment (Farris 2012). In another research administered with Turkish employees, Schroeder (2011) found that LMX can be associated with organizational commitment. According to previous literature we expect that:

$\boldsymbol{H}_{2}$ : High quality LMX positively affects affective commitment.

$\boldsymbol{H}_{3}$ : High quality LMX positively affects normative commitment.

$\boldsymbol{H}_{4}:$ High quality LMX positively affects continuance commitment.

\section{Mediating Role of Job Satisfaction}

The quality of the leader member exchange is critical for organizational success. Previous studies show that high quality of LMX and job satisfaction is among the highest correlated work attitudes. It is observed that job satisfaction may also affect the relationship with leader member relations and other work attitudes, where some previous research show that job satisfaction tend to mediate the relationship between LMX and organizational commitment. Liao et al.(2009) analyzed the cause and effect of relationships among leader-member relations, as well as organizational commitment and job satisfaction utilizing structural equation modeling. The results show that job satisfaction is the mediating variable between organization commitment and leader-member relations. Employees may be more likely to perform extra duties, support, endorse the organization's objectives and have high affective organizational commitment if they have high levels of satisfaction with the job (Ariani, 2012). Hence, we assume that;

$\boldsymbol{H}_{5}$ : Job satisfaction has mediating effect between LMX and affective commitment.

$\boldsymbol{H}_{6}$ : Job satisfaction has mediating effect between LMX and normative commitment.

$\boldsymbol{H}_{7}$ : Job satisfaction has mediating effect between LMX and continuance commitment.

The above mentioned relationships can be observed in the research model given in Figure 1.

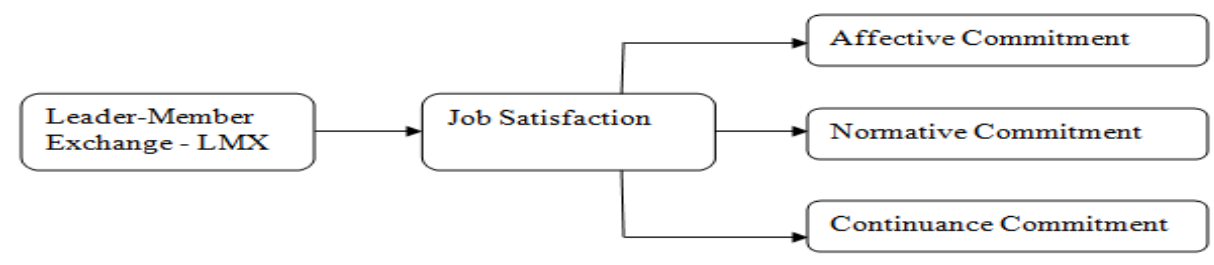

Figure 1 Research Model

\section{METHODOLOGY}

\section{Research Goal}

In this survey we aim to identify the mediating role of job satisfaction on the relationship between organizational commitment and LMX. To test the propositions, a field survey using questionnaires was conducted. 


\section{Sample and Data Collection}

The questionnaires were distributed to a number of selected companies facilitating in both service and production industries, located in Istanbul. Some of the data were collected via hard copies, while some through a web-based digital survey tool, set up by the present researchers. In total, 400 questionnaires were distributed, of which 210 were received. Four of the questionnaires were excluded, for the missing values. As a result, 206 questionnaires were used and this yielded a return rate of $49.2 \%$.

Male respondents comprised $42.6 \%$ and females $57.4 \%$ of the sample. $48.8 \%$ of the respondents had an undergraduate degree, $36.3 \%$ master, $7 \% \mathrm{PhD}$ and $8 \%$ had only lyceum degrees. Average tenure of respondents in their current job is 5.82. Respondents were aged between 20 to 60 and average age of respondents was 34.21 .

\section{Measurement Instruments}

Liden \& Maslyn's (1998) 11- item psychometrically tested scale (LMX-MDM) measuring LMX in four factors have been used. The scale measures LMX in dimensions such as "loyalty", "affect","professional respect" and perceived "contribution to the exchange".

Measurement instrument of job satisfaction included four items from Hackman and Oldham (1975). A six-point Likert-type scale, with anchors of "totally agree" to "totally disagree" was used to collect responses.

Organizational commitment was measured in three dimensions: affective, normative and continuance. These 33 questions were taken from Wasti's (1999) doctoral dissertation. As in the Job Satisfaction Questionnaire, a six-point Likert--type scale, with anchors of "totally agree" to "totally disagree" was used to collect responses.

\section{Correlation Analysis}

The interrelationships among variables, their mean values and Standard deviations are shown in Table 1

Table 1 Inter-Correlation Among Variables

\begin{tabular}{llllllll}
\hline Scale & N & Avg. & St. Dev. & 1 & 2 & 3 & 4 \\
\hline Loyalty & 202 & 3,20 & 1,27 & - & & & \\
Necessity & 205 & 3,53 & 1,24 & $.173^{*}$ & - & & \\
Continuance & 206 & 3,53 & 1,30 & $.160^{*}$ & $.392^{* *}$ & - & \\
LMX & 204 & 3,10 & 1,42 & $.593^{* *}$ & $-.185^{* *}$ & .117 & - \\
Satisfaction & 204 & 3,17 & 1,31 & $.779^{* * *}$ & .043 & .024 & $.604^{*}$ \\
\hline
\end{tabular}

$* * *<0,001 * *<0,05$

\section{Factor Analysis}

Organizational Commitment: The factor structure of this instrument was analyzed using principal components analysis with varimax rotation. This analysis yielded three factors with eigen values over 1.00 that explained $69 \%$ of the total variance. The factor structure and loadings are given in Table 2 .

Leader-Member Exchange: The factor structure of this instrument was analyzed using principal components analysis with varimax rotation. This analysis yielded only one factor. That is why, factor analysis could not completed.

Job Satisfaction: Because of the low number of items, factor analysis could not be applied for job satisfaction. 
Table 2 Factor Analysis For Organizational Commitment

\begin{tabular}{llcc}
\hline Organizational Commitment & Factor Variance & Factor Loadings & Cronbach Alpha \\
\hline 1st Factor: LOYALTY & 40,434 &, 937 &, 935 \\
AC3 & &, 919 & \\
AC4 & &, 884 & \\
AC5 & &, 872 & \\
AC6 & &, 834 & \\
AC2 & &, 736 &, 770 \\
AC1 & &, 659 & \\
NC6 &, 647 & \\
NC1 & 18,919 &, 822 &, 780 \\
NC5 & &, 815 & \\
2nd Factor: NECESSITY &, 657 & \\
NC2 & &, 619 & \\
NC3 & &, 822 & \\
CC6 &, 801 & \\
CC5 & & & \\
3rd Factor: CONTINUANCE & 17,285 & & \\
CC2 & & & \\
CC1 & & & \\
CC3 & & & \\
\hline KMO: 0,89 & & & \\
p: 000 (Bartlett's Test) & & & \\
\hline
\end{tabular}

\section{The Mediating Role of Job Satisfaction}

As can be seen in the research model, job satisfaction was assumed to mediate the relationship between LMX and organizational commitment. To test mediating effect of job satisfaction, three stages multiple regression method was used (Baron and Kenny, 1986). Baron and Kenny (1986) indicate that to test for mediation, three regression equations should be estimated. First, the mediator should be regressed on the independent variable; second, the dependent variable should be regressed on the independent variable and; third, the dependent variable should be regressed both on the mediator and on the independent variable. In order to have a mediating effect the following conditions should be met: independent variable should affect the mediator in the first equation; it should also affect the dependent variable in the second equation; and mediator should not only affect the dependent variable in the third equation but also the effect of the independent variable on the dependent variable should be less in the third equation than in the second one.

In accordance with the above mentioned method in the first level, job satisfaction was regressed on LMX. LMX was observed to have a significant effect on job satisfaction. (Table 3). Therefore, H1 is supported In the second level of three stages multiple regression analysis, organizational commitment was regressed on LMX. Results indicated that; among organizational commitment dimensions; LMX has significant effect only on loyalty and necessity (Table 3). So, $\mathrm{H} 2$ and $\mathrm{H} 3$ are supported. In the third level, organizational commitment was regressed on LMX and job satisfaction. As a result, only significant results were found only for loyalty. Thus, job satisfaction had a significant mediating effect between LMX and loyalty. Job satisfaction does not have any significant mediating effect between LMX and other organizational commitment dimensions (Table 3). Therefore, H5 is supported 
Table 3 The Mediating Role Of Job Satisfaction On Lmx And Commitment, Three-Step Regression Analysis

\begin{tabular}{llll}
\hline $\begin{array}{l}\text { First Level } \\
\text { Component }\end{array}$ & Job Satisfaction & & \\
\hline LMX &, $604^{* * * *}$ & & \\
$\mathbf{R}^{2}$ & 0,364 & & \\
Adjusted $\mathbf{R}^{2}$ &, $361^{* * *}$ & & Continuance \\
F Value & $113,502^{* * *}$ & & \\
\hline Second Level & Loyalty & Necessity & 0,117 \\
Component & & & 0,014 \\
\hline LMX &, $593^{* * *}$ & 0,009 \\
$\mathbf{R}^{2}$ & 0,352 &,$- 185^{* *}$ & 2,753 \\
Adjusted $\mathbf{R}^{2}$ & 0,348 & 0,034 & \\
F Value & $106,897^{* * *}$ & 0,029 & \\
\hline Third Level & Loyalty & $7,079^{* * *}$ & \\
Component & & Necessity & \\
\hline LMX &, $190^{* * * *}$ & & \\
Job Satisfaction &, $667^{* *}$ & $-075^{* *}$ & \\
$\mathbf{R}^{2}$ & 0,633 & $-0,036$ & \\
Adjusted $\mathbf{R}^{2}$ & 0,629 & 0,051 & \\
$\mathbf{R} 2$ Difference &, $282^{* * *}$ & 0,041 & \\
F Value & $167,504^{* * *}$ & $5,172^{* * *}$ & \\
\hline Independent variables & LMX, Job Satisfaction & \\
\hline
\end{tabular}

Independent variables: LMX, Job Satisfaction

Dependent variables: Loyalty, Necessity, Continuance

${ }^{*} \mathrm{p}<0,05^{* *} \mathrm{p}<0,01{ }^{* * *} \mathrm{p}<0,001$

\section{The Relationship between Job Satisfaction and Gender}

The relationship between these two variables was tested by t-test. Based on the results, female employees have higher job satisfaction levels than male employees. T-test results were presented in Table 4.

Table 4 Gender And Job Satisfaction

\begin{tabular}{|l|l|c|c|c|c|c|}
\hline & & $\mathbf{N}$ & Average & $\begin{array}{c}\text { Standart } \\
\text { Deviation }\end{array}$ & t value & p value \\
\hline Job Satisfaction & Female & 113 & 3,41 & 1,36 & 2,788 &, 006 \\
& Male & 85 & 2,89 & 1,22 & \\
\hline
\end{tabular}

\section{CONCLUSION}

\section{Discussion}

This Current research has aimed at determining the effect of both leader-member relations (LMX) and job satisfaction on organizational commitment; taking job satisfaction as mediating factor. We have followed a few steps of analysis: factor analysis of scales -LMX, job satisfaction and organizational commitment; regression analysis; and finally t-test to predict gender and job satisfaction. 
As first step of factor analysis, the factor analysis for job satisfaction was not applied, since there are few items on job satisfaction scale. Detailed results about the factor analysis were given in previous section.

In the second step -LMX factors, the scale was assumed to measure four factors; however, in this current research we found that items were yielded to only one factor. This might be a result of cultural difference, that Turkish employees have the tendency to evaluate their leaders only in one dimension when they like one attitude, it may influence other features of leaders. Therefore, in this research, any difference among factors was not found and was regarded as one. Another reason might be because of the few items that measures LMX factors; a scale with more items may affect the results differently.

As third step, in the factor analysis of organizational commitment items, three factors were found, however they are found to be different from the literature's factors of commitment (affective, continuance and normative); they are loyalty, necessity and continuance. The continuance factor is determined as mentioned in the literature; nonetheless, the affective and normative commitment items were mixed, as if the items were weighted for different factors than the assumed ones, thus leading us to consider them as one factor. There are similar results in previous literature; Unler (2006) for example, also found different factors for organizational commitment. Cultural differences may also affect this result, where Turkish employees may have different attitudes for organizational commitment. In that sense, in future researches, statements of the items in the organizational scale might be needed to be adapted into Turkish culture.

In the regression analysis, the first one was applied to job satisfaction and LMX. According to this, it was found that high quality LMX positively affect job satisfaction; thus the first hypothesis $-\mathrm{H}_{1}$, was accepted. This result also confirms previous research; LMX and job satisfaction was found to be positively correlated in previous researches ( $\mathrm{Li}$ et al 2010, Harris et al. 2009). The three stage of regression analysis between organizational commitment and LMX resulted with LMX affecting loyalty and necessity commitment; thus $\mathrm{H}_{2}$ and $\mathrm{H}_{3}$ were supported. These results also support previous literature: Liao et al. (2009) claimed that LMX affects contribution and loyalty dimensions of organizational commitment; Golden \& Veiga (2008) stated that high quality leader member relationship causes mutual trust, liking and respect; Dienesch and Liden (1996) stated that high LMX members enjoy high exchange quality relationships as characterized by liking, loyalty, professional respect, and contributory behavior (Ariani 2012).

As main purpose of the study, the mediating affect of job satisfaction on relation between LMX and organizational commitment was measured, and it was found that job satisfaction mediates (by $60 \%$ ) the relationship between loyalty commitment and LMX. Thus, $\mathrm{H}_{5}$ has been supported. This also supports previous literature: Ariani (2012) stated that if employees have higher level of job satisfaction they prefer to show extra support to organization and do extra duties.

When gender differences in job satisfaction were measured, it was found that female employees have higher job satisfaction level than their male workmates. This result is concurrent with the previous literature as well: Clark (1997) and Poza and Poza (2003) also found that women have higher job satisfaction levels than men. The underlying reason of this result is explained through the fact that, female employees give importance to their employment more than males. For women, working outside of their home is more valued as it creates opportunity to attain other skills than their family responsibilities. That is why, they are more willing to be satisfied with their organizations.

\section{Managerial Implications}

LMX recommends that leaders work to establish a good relationship with every follower (Graen \& Uhl-Bien, 1995), in other words, attempt to explain how the quality of relationship between leaders and subordinates affects on the organizational outcomes over time (Lussier \& Achua, 2004). The nature of the LMX relationship can have a major impact on overall individual and organizational success. Human capital have taken a central role in building a firm's competitive advantage in today's environment, 
According to the findings of our study, the high level of relationship (high LMX) between managers and employees elicits job satisfaction and this satisfaction results increasing performance of employees. Performance of the subordinates, developing more high quality LMX relationships with members, will enhance overall success of the organization. Graen et al., (2004) emphasized that leaders should offer the opportunity to develop high quality LMX relationships to all of their subordinates.

One obvious implication of the present study is that leaders should be aware of the important linkages between job satisfaction, organizational commitment, and performance. Supervisors need to be aware of how to maximize high LMX relationships among their subordinates. They can do so by giving some of their followers support and acknowledgment, allowing them to participate in decision making, delegating on them important team tasks, talking and listening them about their concerns and expectations (Graen et al., 1982 and Yukl, 2009).

\section{Future Directions and Limitations}

Results explained above are based on research conducted with limited number of respondents -209, and within the service and production industries located in Istanbul. Therefore they cannot be generalized to the Turkish population. In order to reinforce these results and justify the positive relationship between LMX and organizational commitment, and the mediating role of job satisfaction on this relation within the Turkish context, this research is needed to be repeated for larger sample in Turkey. As aforementioned, the statements of some items - specifically in the organizational commitment scale, may be needed to be re-adapted into the Turkish culture, so as the research reflects the concrete perspective of Turkish employees. 


\section{REFERENCES}

Ariani, Dorothea, Wahyu, (2012), "Leader-member exchanges as a mediator of the effect of job satisfaction on affective organizational commitment: An empirical test". International Journal of Management, 29 (1): 46-56.

Asgani, Ali\& Silong, Abu Daud\& Ahmad, Aminoh\& AbuSama, Battaman, (2008), The relationship between transformational leadership behaviors, LMX \& Organizational Citizenship Behaviors, Journal of Social Sciences, 6,4.

Barbuto, John E. \& Hayden, Robert W., (2011), Testing relationship between Servant Leadership dimensions and leader-member exchange (LMX), Journal of Leadership Education, 10,2.

Baron, M. Reuben. \& Kenny, David, A. (1986). "The Moderator-Mediator Variable Distinction in Social Psychological Research: Conceptual, Strategic, and Statistical Considerations". Journal of Personality and Social Psychology, 51 (6):1173-1182.

Bass,Bernard \& Bass, Ruth, (2008). The Bass Handbook of Leadership: Theory, Research and Managerial Applications.

Berneth, Jeremy B. \& Armenakis, Achilles A. \& Field, Hubert S. \& Giles, William F. \& Walker, H. Jack, (2007), Is personality associated with perception of LMX? And empirical study, Leadership \& Organization Development Journal, 28, 7: 613-631.

Breukelen, Wim van \&Schyns, Birgit \& Le Blanc, Pascale , (2006), Leader-Member Exchange Theory and Research: Accomplishments and Future Challenges, Leadership, 2,3: 295-316.

Clark, Andrew, E. (1997), "Job satisfaction and gender: why are women so happy at work?" Labour Economics, 4: 341-72.

Connell, Patrick W, (2005), Transformational leadership, leader-member exchange (LMX), and OCB: The role of motives, Graduate School Theses and Dissertations, http://scholarcommons.usf.edu/etd/2833 Dansereau, Fred\& Yammarino, Francis J, 2002, Individualized Leadership, Journal of Leadership, 9,1: 90-99.

Duong, Julie, (2011), Leaders' conceptions and evaluations of followers as antecedents of leadership style, leader-member exchange, and employee outcomes, Unpublished doctoral thesis, Marshall Goldsmith School of Management Alliant International University, Los Angeles.

Farris, Jeremy, R., (2012), Organizational commitment and job satisfaction: A quantitative investigation of the relationships between affective, continuance, and normative constructs. Unpublished doctoral thesis, Capella University, Minneapolis.

Fisk, Glenda, M., \& Friesen Jared, P., (2012), "Perceptions of leader emotion regulation and LMX as predictors of followers' job satisfaction and organizational citizenship behaviors", The Leadership Quarterly, 23: 1-12.

Forsyth, Donelson, (2009), Group Dynamics, $5^{\text {th }}$ edition, Lengage Learning Press : 271-274.

Graen, George B: \& Uhl-Bien, Mary, (1995), Relationship based approach to leadership: Development of LMX Theory of leadership over 25 years: Applying a Multi-Level Multi Domain Perspective, Leadership Quarterly, 6,2: 219-247.

Green, Connie B. \& Craven, Annette E. \& Scott, Jeannie, (2006), Exploration of the Relationship between LMX and Demographic Variables, Journal of Business \& Economics Research, 4, 12: 37-50.

Golden, Timothy, D., \& Veiga, John, F., (2008), “The impact of superior-subordinate relationships on the commitment, job satisfaction, and performance of virtual workers", The Leadership Quarterly, 19: $77-88$.

Hackman, J. Richard \& Oldham, Greg. R. (1975), "Development of the job diagnostic survey.". Journal of Applied Psychology, 60:159-170. 
Harris, Kenneth, J., Wheeler, Anthony, R., \& Kacmar, Michele, K., (2009), "Leader-member exchange and empowerment: Direct and interactive effects on job satisfaction, turnover intentions, and performance".The Leadership Quarterly, 20: 371-382.

Howell, Jane M. \& Hall, Merenda, Kathryn E., (1999), The ties that bind: The Impact of LMX, transformational and transactional leadership, and distance on predicting follower performance, Journal of Applied Psychology, 84,5: 680-694.

Ishak, Noormala Amir, (2009), Leader-Member Exchange and OCB: The mediating Impact of SelfEsteem, International Journal of Business and Management, 4,3: 52-61.

Joo, Brian, (2010), “Organizational commitment for knowledge workers: The roles of perceived organizational learning culture, leader-member exchange quality, and turnover intention". Human Resource Development Quarterly, 21 (1): 69-85.

Kang, Dae-seok, Stewart, Jim, \& Kim, Hayeon, (2011), “The effects of perceived external prestige, ethical organizational climate, and leader-member exchange (LMX) quality on employees' commitments and their subsequent attitudes", Personnel Review, 40 (6): 761-784.

Kim, BeomCheol Peter \& Lee, Gyumin \& Carlson, Kevin D., (2010), An examination of the nature of the relationship between Leader-Member Exchange (LMX) and turnover intent at different organizational levels, International Journal of Hospitality Management, 29, 591-597.

Le Blanc, Pascale, M., \& Gonzalez-Roma, Vicente, (2012), “A team level investigation of the relationship between Leader-member exchange (LMX) differentiation, and commitment and performance", Leadership Quarterly, 23: 534-544.

Li, Ning, Liang, Jian, \& Crant, J. Micheal, (2010), “The role of proactive personality in job satisfaction and organizational citizenship behavior: A relational perspective". Journal of Applied Psychology, 95 (2): 395-404.

Li Ma and Qing Qu, 2010, Differentiation in leader-member exchange: A hierarchical linear modeling approach, The Leadership Quarterly, 21,5: 733-744.

Liao, Shu-Hsien, Hu, Da-Chian, \& Chung, Hui-Ying, (2009), "The relationship between leader member relations, job satisfaction and organizational commitment in international tourist hotels in Taiwan”, The International Journal of Human Resource Management, 20 (8): 1810-1826.

Liden, Robert C \& Wayne, Sandy J. \& Zhao, Hao\& Henderson, David, (2008), Servant Leadership: Development of Multidimensional measure and Multi-level Assessment, The Leadership Quarterly, 19,2: 161-177.

Liden, Robert, C. \& Maslyn, John, M. (1998), "Multi- dimentionality of LMX: An empirical assessment through scale development", Journal of Management, 24:43-72.

Mardanov, Ismatilla, T., Maertz, Carl,. P., \& Sterrett, Jack. L., (2008), "Leader-member exchange and job satisfaction”, Journal of Leadership Studies, 2 (2): 63-82.

Mardanov, Ismatilla, T., Heischmidt, Kenneth \& Henson, Amy, (2008), "Leader-member exchange and job satisfaction bond and predicted employee turnover", Journal of Leadership \& Organizational Studies, 15 (2): 159-175.

Ndoria, Jefferson, (2012), Servant Leadership: Is it an Academic Jargon or a Lifestyle? Servant Leadership Research Roundtable, Regent University School of Leadership Studies.

Ngoma, Sylvester, (2012), Leader-Member Exchange and Shared Leadership: A Blended Model of IT Leadership, Ph.D. Thesis.

Northouse, Peter, G., (2013), 'Leadership Theories and Practices', $6^{\text {th }}$ ed., Sage Publications, Los Angeles, USA.

O’Connor, Christine \& Srinivasan, Sanjeev, (2010), "Influence of employment type of LMX, organizational commitment and job satisfaction". Employment Relations Record, 10 (2): 75-93. 
O’Donnel, Mark \& Yukl, Gary \& Taber, Thomas, (2012), Leader behavior and LMX: a constructive replication, Journal of Psychology, 27, 2: 143-154.

Pellegrini, Ekin K. \& Scandura, Terri A.,( 2006), Leader-member exchange (LMX), paternalism, and delegation in Turkish business culture: An empirical investigation, Journal of International Business Studies, 37, 264-279.

Pellegrini, Ekin K. \& Scandura, Terri A.,\& Jarayaman,Vaidyanathan, (2010), Cross-Cultural Generalizability of Paternalistic Leadership: An Expansion of Leader-Member Exchange Theory, Group \& Organization Management, 35,4: 391- 420.

Sanders, Karin \& Moorkamp, Matthijs \& Torka, Nicole \& Groeneveld, Sandra \& Groeneveld, Claudia, (2010), How to support innovative behavior? The role of LMX and satisfaction with HR practices, Technology and Investment, 1, 59-68.

Scandura, Terri A; Schriesheim, Chester A, (1994), Leader-member exchange and supervisor career mentoring as co, Academy of Management Journal, 37,6: 1588.

Schyns, Birgit \& Day, David, (2010), Critique and review of leader-member exchange theory: Issues of agreement, consensus, and excellence, European Journal of Work and Organizational Psychology, 19:1, 1-29.

Schroeder, Jennifer, L., (2011), The impact of paternalism and organizational collectivism in multinational and family-owned firms in Turkey, Unpublished master thesis, College of Arts and Sciences University of South Florida, Florida.

Sears, Greg J. \& Hackett, Rick D., (2011), The influence of role definition and affect in LMX: A process perspective on the personality - LMX relationship, Journal of Occupational Psychology, 84, 544-564.

Shiva, M.S.A. Mahalinga \& Suar, Damodar, (2010), Leadership, LMX, Commitment and NGO Effectiveness: Transformational Leadership, Leader-Member Exchange, Organizational Commitment, Organizational Effectiveness and Programme Outcomes in Non-Governmental Organizations, International Journal of Rural Management, 6,117: 117-150.

Sousa-Poza, Alfonso \& Sousa-Poza, Andres, A. (2003), "Gender differences in job satisfaction in Great Britain, 1991-2000: permanent or transitory?", Applied Economics Letters, 10(11):691-694.

Tse, Herman \& Lam, Wing, (2008), 'Transformational leadership and turnover: The role of LMX and organizational commitment. Annual Meeting of the Academy of Management, Anaheim, California, USA.

Truckenbrodt, Yolanda, B., (2000), "The relationship between leader-member exchange and commitment and organizational citizenship behavior”, Acquisition Review Quarterly, Summer: 233244.

Ünler, Ela. (2006), “Örgüte Bağlılığın İşin Nitelikleri ve Davranış Düzeltme Uygulamasıyla İlişkisi”, Çanakkale Onsekiz Mart Üniversitesi Biga İktisadi ve İdari Bilimler Yönetim Bilimleri Dergisi, 4(1): 95-115.

Van Breukelen, Wim \& Schyns, Birgit \& Le Blanc, Pascale, (2006), Leader Member Exchange Theory and Research: Accomplishments and Future Challenges, Leadership 2006, 2:295.

Volmer, Judith, Niessen, Cornelia, Spurk, Daniel, Linz, Alexandra, \& Abele, Abele, E., (2011), "Reciprocal relationships between leader-member exchange (LMX) and job satisfaction: A crosslagged analysis", Applied Psychology: An International Review, 60 (4): 522-545.

Wasti, Arzu, S.,(1999). Organizational commitment and collectivism: The case of Turkey, Unpublished doctoral dissertation, University of Illinois, Urbana-Champaign. 